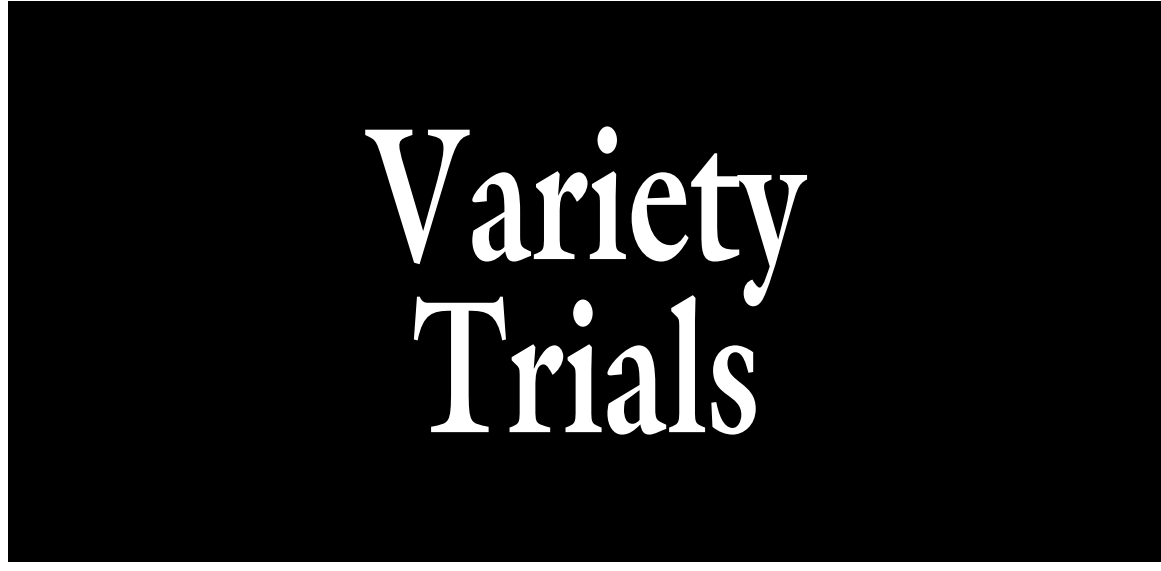

\title{
Performance of Muscadine Grape Cultivars in Southern Mississippi
}

\author{
Stephen J. Stringer ${ }^{1,3}$, Donna A. Marshall ${ }^{1}$, Blair J. Sampson ${ }^{2}$, \\ and James M. Spiers ${ }^{1}$
}

ADDITIONAL INDEX wORDS. Vitis rotundifolia, vigor, disease resistance, fruit quality

Summary. A study was conducted at the Mississippi State University Agricultural and Forestry Experiment Station (MAFES) McNeil Unit in southern Mississippi to identify promising muscadine grape (Vitis rotundifolia) germplasm for use as parents in the breeding and genetics research program and to develop information on performance for use by growers in the region for cultivar selection decisions. The vineyard was first established in 1992 and was expanded in 1994. Cultivars were evaluated in 2001, 2002, and 2006 for their performance and were found to differ in vigor, resistance to diseases, yield, and fruit quality. Cultivars suitable for winemaking that performed well included Carlos, Doreen, Magnolia, Noble, Regale, Sterling, and Welder. Cultivars intended for the fresh market that produced high yields and high-quality fruit included Alachua, Black Beauty, Darlene, Fry, Ison, Janebell, Nesbit, Polyanna, Sweet Jenny, Summit, and Tara. 'Dixie', a multipurpose cultivar, 'Eudora', a newly released fresh-market cultivar, and 'Southern Home', a multipurpose cultivar with enhanced ornamental value, also performed well at this location.

$\mathrm{T}$ The muscadine grape is indigenous to the southeastern United States and has the distinction of being the first cultivated grape in North America. Native Americans prized the muscadine grape for its distinctive, savory, and delectable flavor and pleasant aroma. The nutritional value of muscadine grapes is excellent as they provide a rich source of fiber, essential amino acids, minerals, and vitamins (Ector, 2001) Muscadine gapes are still

${ }^{1}$ U.S. Department of Agriculture, Agricultural Research Service, Thad Cochran Southern Horticulture Laboratory, Poplarville, MS 39470

${ }^{2}$ Mississippi State University, Agricultural and Forestry Experiment Station, McNeil Unit, South Mississippi Branch, Poplarville, MS 3947

${ }^{3}$ Corresponding author. E-mail: stephen.stringer@ ars.usda.gov. consumed as fresh fruit and are used for producing juice, preserves, and sweet table wines. Muscadine grape pomace, which until recently was discarded as waste, is now being sought after for utilization as food additives and dietary supplements due its nutraceutical value. Muscadine grape skins and seeds contain high concentrations of stilbene compounds, including anthocyanins and phenolics (Basiouny, 2001; Ector, 2001), whose production in the muscadine grape plant evolved as defense mechanisms against attacks by fungal pathogens. Laboratory studies have demonstrated that these compounds benefit human health by preventing diseases arising from inflammation and ranging from heart disease to cancer (Basiouny, 2001; Hartle et al., 2005; Maas et al., 1991). These recent findings support an unprecedented potential expansion of the muscadine grape industry for fresh, processed, and specialty muscadine grape products (Morris and Brady, 2004).

Unlike other grape species, the inherent resistance or, in some cases, tolerance, of muscadines to diseases including pierce's disease (Xylella fastidiosa) and various fungal pathogens enables sustainable production in the southeastern United States (Basiouny, 2001; Hopkins, et al., 1974; Morris and Brady, 2004; Mortensen et al., 1977; Olein 1990). In the early 1980s, commercial farm land devoted to this specialty crop was estimated at 4000 acres (Olein, 1990). Although early muscadine grape cultivars (e.g., Scuppernong) were selected from wild populations, plant breeders have steadily improved germplasm and have developed improved cultivars for over 100 years (Armstrong et al., 1934; Husman and Dearing, 1913; Mortensen, 2001; Olein, 1990). Over 50 older and newer cultivars can currently be found growing in dooryard plantings and commercial vineyards.

For muscadine grape growers to make appropriate decisions when considering cultivars for new plantings, an understanding of the differences among them, particularly in their potential for producing high yields of quality fruit is essential. Cultivar selection decisions require an understanding of several important factors ranging from pollination

\begin{tabular}{llll}
\hline $\begin{array}{l}\text { Units } \\
\text { To convert U.S. to SI, } \\
\text { multiply by }\end{array}$ & U.S unit & SI unit & $\begin{array}{l}\text { To convert SI to U.S., } \\
\text { multiply by }\end{array}$ \\
\hline 0.3048 & $\mathrm{ft}$ & $\mathrm{m}$ & 3.2808 \\
3.7854 & gal & $\mathrm{L}$ & 0.2642 \\
25.4 & inch(es) & $\mathrm{mm}$ & 0.0394 \\
0.4536 & $\mathrm{lb}$ & $\mathrm{kg}$ & 2.2046 \\
1.6093 & $\mathrm{mile}(\mathrm{s})$ & $\mathrm{km}$ & 0.6214 \\
28.3495 & $\mathrm{oz}$ & $\mathrm{g}$ & 0.0353
\end{tabular}


biology to end-use markets. The biology of muscadine grape pollination is of importance because currently grown cultivars are hermaphroditic, possessing perfect self-fertile flowers or they are female, possessing pistillate flowers that require pollen from a different perfect flowered cultivar for fertilization and fruit-set to occur (Goffinet et al., 2001; Sampson et al., 2001). From a marketing standpoint, cultivar selection should be based upon intended end-usages. Ideally, all muscadine grape cultivars should grow vigorously with and possess a high yield potential and resistance to fungal pathogens affecting plant health and fruit quality. The fresh market demands cultivars that develop large flavorful berries having edible skins, high soluble content, and a relatively low percentage of fruit with wet picking scars (skin tears resulting from forced removal of fruit from the pedicel). Another important trait, fruit skin color, varies among cultivars ranging from black to bronze, and bronze types are sometimes considered more attractive and preferred by fresh muscadine grape consumers. Fruit of cultivars suitable for juice production should also posses relatively even ripening, and stable skin pigments that are resistant to oxidation and browning when stored and when fermented for production of quality wines (Mortensen, 2001; Olein, 1990).

Once growers have determined the cultivars most suitable for a particular end usage, knowledge of their potential for performance in a given geographic region is critical to ending decisions. Performance studies provide reliable information and insight into a cultivars' potential for commercial production in different environments. Trials to evaluate the performance of muscadine grape cultivars were conducted in Arkansas and Florida during the last several decades (Clark, 2001; Moore, 1972; Moore and Bowden, 1976; Mortensen and Balderdi, 1973; Mortensen and Harris, 1989; Striegler et al., 2005). Several new cultivars have been developed and released by various public and private breeding programs since these studies were conducted (Mortensen, 2001). Acreage devoted to muscadine grape production in the Gulf of Mexico coast region of the U.S., and in the state of Mississippi, already the home of one of the nation's largest single muscadine vineyards (about $68 \mathrm{ha}$ ), is expected to expand with increasing demand. Information on the performance of different cultivars in the region is, however, limited. Thus, this study was conducted to develop information on pomological characteristics and the performance of selected established and newer muscadine grape cultivars for use in the breeding and development of new muscadine grape germplasm and to provide growers in the region with information on cultivar performance to assist in their selection of the best cultivars for their desired purposes.

\section{Materials and methods}

The muscadine grape vineyard was established within the U.S. Department of Agriculture (USDA) Hardiness zone 8a (Cathy, 1990) at the Mississippi State University MAFES McNeil Unit, on a Ruston silt loam soil (USDA, 1983) in 1992 and was expanded in 1994. The cultural practices followed were based on recommendations for commercial muscadine grape production (Braswell, et al., 2001; Himelrick, 2001). The vines were spaced $6 \mathrm{~m}$ apart in the row with 4-m spacing between rows. Geneva double curtain trellises were used to train vines along two bilateral cordons at a height of $5 \mathrm{ft}$ on each of the two trellis wires. Each year after plants had reached 5 years of age, plants were fertilized with $0.25 \mathrm{lb}$ nitrogen $(\mathrm{N}), 0.31 \mathrm{lb}$ phosphorus $(\mathrm{P})$, and $0.5 \mathrm{lb}$ potassium $(\mathrm{K})$ in March and $0.25 \mathrm{lb} \mathrm{N}, 0.11 \mathrm{lb} \mathrm{P}$, and $0.33 \mathrm{lb} \mathrm{K}$ in May, followed by $0.33 \mathrm{lb}$ $\mathrm{N}$ in early July. Timers were used to control drip irrigation of $\approx 3$ gal water per plant on alternate days, except after significant rainfall events. The soil beneath and surrounding the vines was treated in July each year with a $0.005 \%$ chloropyrophos drench for grape root borer control. Labeled preemergence and postemergence herbicides were routinely used to manage weeds. Each winter, vines were spur pruned, leaving two to four buds of the current season's growth to develop new fruiting wood for the following growth season, but during this study, no old spur renewal-type pruning was practiced.

Many of the muscadine cultivars evaluated in this study were also included in trials conducted previously in Arkansas and Florida (Morris and Brady, 2004; Mortensen and Harris, 1989; Striegler et al., 2005), and their pomological traits have been described in recent reviews, production guides, or release notices (Braswell et al., 2001, Brooks and Olmo, 1997; Mortensen, 2001; Stringer et al., 2007). Muscadine grape cultivars tested included Alachua, Albermarle, Black Beauty, Burgaw, Carlos, Cowart, Darlene, Dearing, Dixie, Dixieland, Doreen, Dulcet, Eudora, Fry, Higgins, Hunt, Ison, Janebell, Jumbo, Magnolia, Nesbit, Noble, Pollyanna, Redgate, Regale, Roanoke, Scuppernong, Southern Home, Southland, Sterling, Summit, Sweet Jenny, Tara, Tarheel, Triumph, Watergate, and Welder. Berry skin color and flower type are among important attributes for consideration in cultivar selection and are included in Table 1.

The study location was in a warm temperate humid climate (lat. $30^{\circ} 49^{\prime} 48^{\prime \prime} \mathrm{N}$, long. $\left.89^{\circ} 30^{\prime} \mathrm{W}\right) \approx 80$ $\mathrm{km}$ inland from the Gulf of Mexico, where winter temperatures are seldom sufficiently low to cause freeze damage and vigor reduction to trunks and cordons, and where hot and humid summer conditions may result in severe fungal disease infestations in susceptible cultivars. Observations on vine vigor were based on a subjective scale $(1=$ very poor, $5=$ average, $10=$ very vigorous) of the health of trunk and fruiting wood and total vegetative growth. To evaluate disease resistance, no fungicides were used in this study. Leaf disease symptoms of black rot and angular leaf spot resulting from Guignardia bidwelli and Mycosphaerella anguata, respectively, were observed on susceptible cultivars each year. Disease symptoms present on berries were due to black rot, macrophoma rot (Botryosphaeria dothidea), bitter rot (Greeneria uvicola), ripe rot (Colletrichium acutatum), and russet or "sunburn." Subjective measurements of leaf and fruit rot diseases resistance $(1=$ susceptible, $10=$ resistant $)$ were made on berries each year.

Estimates of yield per vine among the cultivars were obtained each year by conducting a single or double harvest, depending upon their evenness of ripening. All fruit from a randomly selected 1 -m section of vine were hand harvested from plants of each cultivar each year. Typically, fresh-market muscadine grapes ripen 
Table 1. Muscadine grape cultivars evaluated for performance at McNeil, MS, in 2001, 2002, and 2006, and their primary usages, and flower and skin color characteristics

\begin{tabular}{|c|c|c|c|}
\hline Cultivar & Principle usage $^{\mathrm{z}}$ & Flower type & Skin color \\
\hline Alachua & $\mathrm{FCH}$ & Perfect & Black \\
\hline Albermarle & J1JuFH & Pistillate & Black \\
\hline Black Beauty & $\mathrm{FCH}$ & Pistillate & Black \\
\hline Burgaw & FW & Perfect & Black \\
\hline Carlos & WJuFCH & Perfect & Bronze \\
\hline Cowart & WFCH & Perfect & Black \\
\hline Darlene & $\mathrm{PFCH}$ & Pistillate & Bronze \\
\hline Dixie & WJFPH & Perfect & Bronze \\
\hline Dixieland & $\mathrm{FCH}$ & Perfect & Bronze \\
\hline Doreen & WJH & Perfect & Bronze \\
\hline Dulcet & $\mathrm{JIFH}$ & Pistillate & Black \\
\hline Fry & $\mathrm{PFH}$ & Pistillate & Bronze \\
\hline Higgins & FWH & Pistillate & Bronze \\
\hline Hunt & J1JuFH & Pistillate & Black \\
\hline Ison & $\mathrm{FCH}$ & Perfect & Black \\
\hline Janebell & FW & Perfect & Bronze \\
\hline Janet & $\mathrm{PF}$ & Perfect & Bronze \\
\hline Magnolia & J1JuWFH & Perfect & Bronze \\
\hline Nesbit & $\mathrm{FH}$ & Perfect & Black \\
\hline Noble & JuW & Perfect & Black \\
\hline Polyanna & $\mathrm{JCH}$ & Perfect & Black \\
\hline Redgate & $\mathrm{FH}$ & Perfect & Red \\
\hline Regale & WJ & Perfect & Black \\
\hline Roanoke & $\mathrm{H}$ & Perfect & Bronze \\
\hline Scuppernong & JWF & Pistillate & Bronze \\
\hline Southland & $\mathrm{FJCH}$ & Perfect & Black \\
\hline Southern Home & $\mathrm{H}$ & Perfect & Black \\
\hline Sterling & JW & Perfect & Bronze \\
\hline Summit & PFJ & Pistillate & Bronze \\
\hline Sweet Jenny & $\mathrm{FCH}$ & Pistillate & Bronze \\
\hline Tara & FHC & Perfect & Bronze \\
\hline Tarheel & JW & Perfect & Black \\
\hline Triumph & $\mathrm{FH}$ & Perfect & Bronze \\
\hline Watergate & WFJ & Pistillate & Bronze \\
\hline Welder & WJu & Perfect & Bronze \\
\hline
\end{tabular}

${ }^{\mathrm{z}} \mathrm{H}=$ home or dooryard, $\mathrm{C}=$ commercial, $\mathrm{W}=$ wine, $\mathrm{Ju}=$ juice, $\mathrm{Jl}=$ jelly, $\mathrm{J}=$ juice or jelly, $\mathrm{F}=$ fresh market, $\mathrm{P}=\mathrm{U}$-pick. Bold letters $=$ cultivars among the most popular for a given usage.

unevenly and are harvested weekly over a period of 4 or 5 weeks, whereas processing muscadines are harvested only once when peak ripeness and optimum soluble solids content occur. As fruit ripening progressed in this study, populations of sugarfeeding insect pests, including bumblebee (Bombus impatiens), paper wasp (Polistes exclamans), and yellowjacket (Vespula maculate), were present in the research vineyard in large numbers each season, and they effectively removed a number of berries from the vines as they ripened. To account for this yield loss, the number of insect-damaged and fallen fruit per meter were counted and their estimated weight (number of fruit $x$ average berry weight) was added to the total yield, and total grams per meter was subsequently converted to kilograms per vine.

Fruit quality factors measured included berry weight, soluble solids content, percentage of dry picking scars, berry firmness, and $\mathrm{pH}$. A randomly selected 20-berry sample was collected to determine mean berry weight. Soluble solids and $\mathrm{pH}$ were determined from juice extracted from a puree from a 40 -g berry sample placed in a commercial Waring ${ }^{\circledR}$ blender (Dynamics Corp. of America, Hartford, CT) and strained through cheesecloth. A hand-held temperaturecompensating refractometer (model AR 200; Leica Microsystems, Wetzlar,
Germany) was used to determine soluble solids concentration. Twentyfive berries from each cultivar were examined for percentage of dry stem scars (i.e., berries lacking skin tears at the point from which they were attached to the stem). Berry firmness measurements were obtained from 20-berry samples run on a Firmtech II (Biotech Corp., Stillwater, OK), an apparatus that measures berry firmness in terms of the force (grams) required to deflect the shape of the fruit $1 \mathrm{~mm}$.

The experimental design was a completely randomized design with three replications of each cultivar analyzed across years. Observations on plant vigor and disease resistance, yield, and fruit quality of the cultivars were made in 200, 2002, and 2006. Data were analyzed using SAS (release 8.2; SAS Institute, Cary, NC). Means of all parameters were presented as bar graphs with standard errors for error bars.

\section{Results and discussion}

Differences in vine vigor among cultivars were noted in this study and average vine vigor ratings were generally higher for black-skinned cultivars than bronze (Figs. 1 and 2) The cultivar displaying the greatest vigor in this study was Southern Home, an interspecific muscadine $\times$ bunch grape hybrid cultivar having dark green and deeply lobed leaves and is suitable for multiple usages and also desirable its ornamental value on dooryard arbors. The least vigorous, 'Scuppernong', is the oldest named cultivar and notably, is still among the most widely grown in hobbyist vineyards. Other cultivars displaying a high degree of vigor (>7.5) included Albermarle, Carlos, Cowart, Eudora, Redgate, Sterling, and Welder. Differences were also noted among cultivars for resistance to leaf diseases (Figs. 3 and 4 ) and a significant correlation $(\mathrm{r}=0.83, P \leq 0.01)$ was detected between vine vigor and resistance to leaf diseases. Cultivars displaying the highest leaf disease resistance ratings $(>7.5)$ were Albermarle, Cowart, Eudora, and Southern Home. Muscadine grape cultivars also differed in susceptibility to several berry rot diseases (Figs. 5 and 6). Black-skinned cultivars were given the highest average berry rot disease resistance rating, 7.69, whereas 


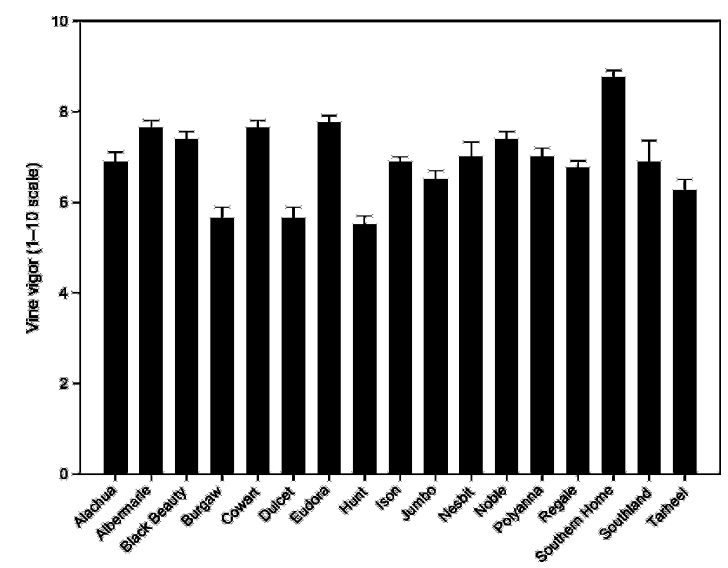

Fig. 1. Average vine vigor ratings of black-skinned muscadine grape cultivars evaluated at $\mathrm{McNeil}$, MS, in 2001, 2002, and 2006. Vine vigor was measured on a scale of 1 to 10 where $1=$ very poor, $5=$ average, and $10=$ very vigorous; error bars $= \pm 1 \mathrm{SE}$.

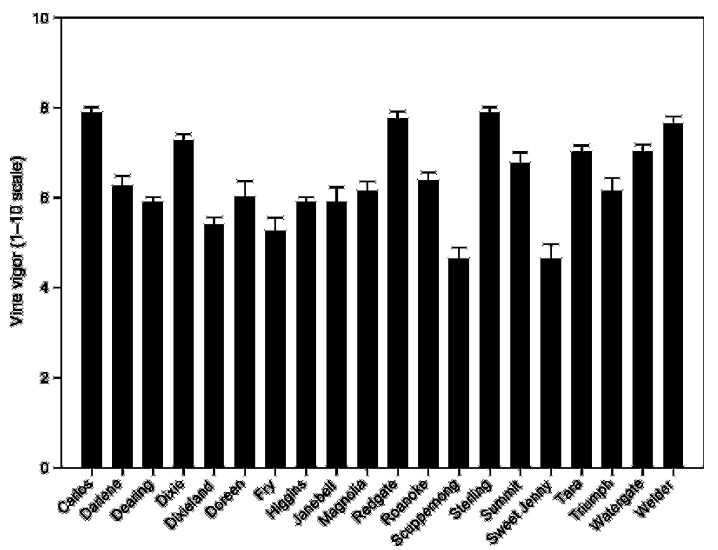

Fig. 2. Average vine vigor of red-and bronze-skinned muscadine grape cultivars evaluated at McNeil, MS, 2001, 2002, and 2006. Vine vigor was measured on a scale of 1 to 10 where $1=$ very poor, $5=$ average, and $10=$ very vigorous; error bars $= \pm 1 \mathrm{SE}$.

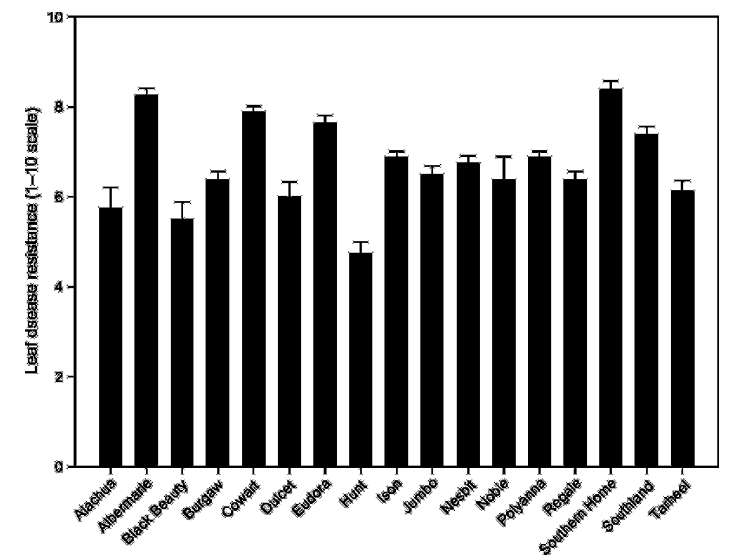

Fig. 3. Average leaf disease resistance ratings of black-skinned muscadine grape cultivars evaluated at McNeil, MS, in 2001, 2002, and 2006. Leaf disease resistance was measured on a scale of 1 to 10 where $1=$ susceptible and $10=$ resistant; error bars $= \pm 1 \mathrm{SE}$.

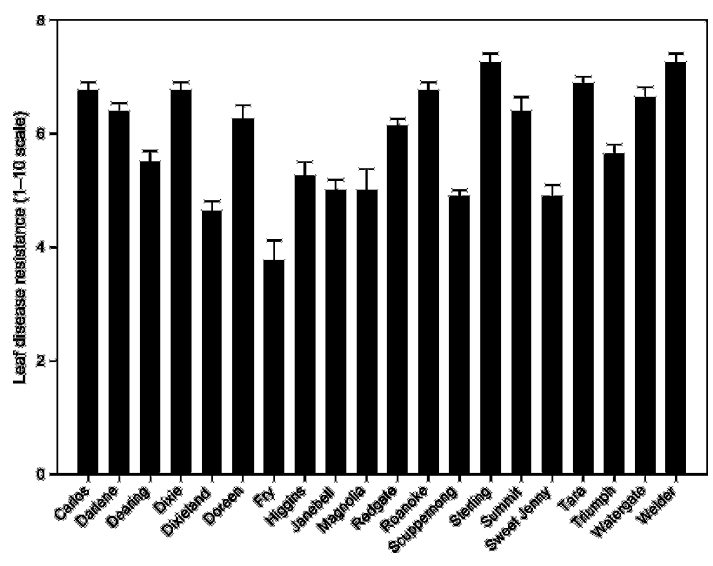

Fig. 4. Average leaf disease resistance ratings of redand bronze-skinned muscadine grape cultivars evaluated at McNeil, MS, in 2001, 2002, and 2006. Leaf disease resistance was measured on a scale of 1 to 10 where 1 = susceptible and 10 = resistant; error bars $= \pm 1$ SE.

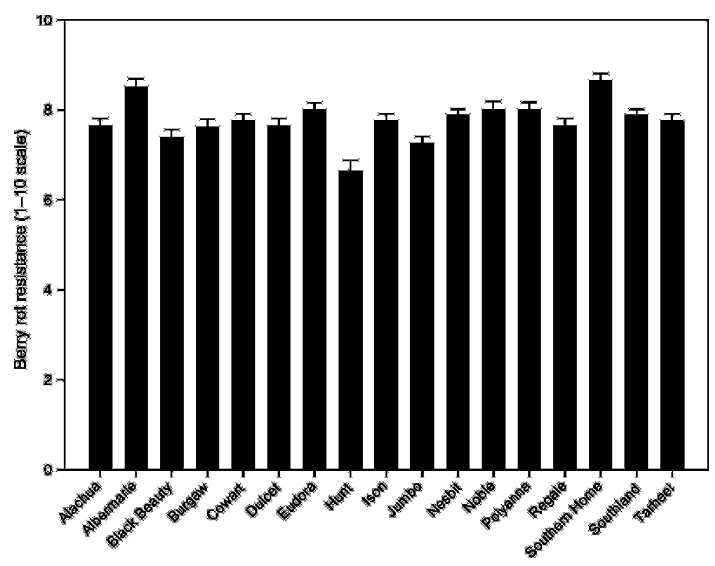

Fig. 5. Average berry rot resistance ratings of blackskinned muscadine grape cultivars evaluated at McNeil, MS, in 2001, 2002, and 2006. Berry rot resistance was measured on a scale of 1 to 10 where $1=$ susceptible and $10=$ resistant; error bars $= \pm 1 \mathrm{SE}$.

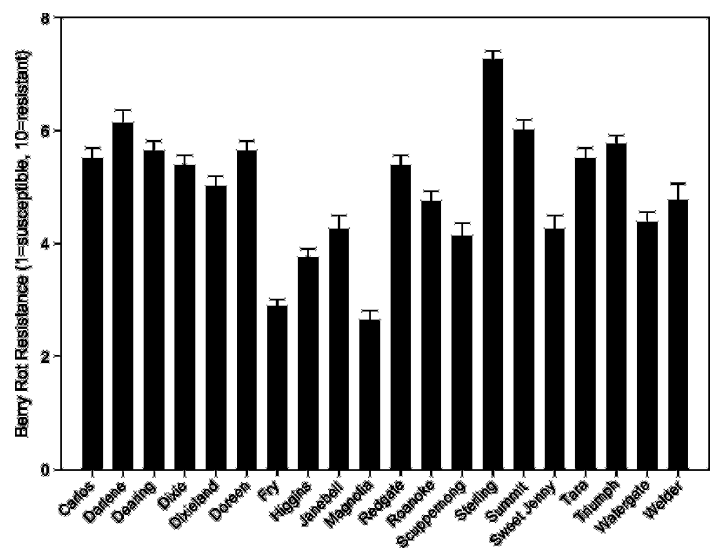

Fig. 6. Average berry rot resistance ratings of redand bronze-skinned muscadine grape cultivars evaluated at McNeil, MS, in 2001, 2002, and 2006. Berry rot resistance was measured on a scale of 1 to 10 where 1 = susceptible and 10 = resistant; error bars $= \pm 1$ SE. 
bronze-skinned cultivars were consistently among the least resistant cultivars and were given an average resistance rating of 4.94. Alachua, Albermarle, Dulcet, Eudora, and Southern Home were the cultivars displaying the highest level of resistance to berry rot diseases. A significant correlation was detected between berry rot diseases and leaf disease resistance $(\mathrm{r}=0.61, P \leq 0.01)$. Because the most resistant cultivars were all black-skinned, it is suggested that a relationship exists between berry skin pigmentation and phytoalexins associated with resistance to fungal pathogens in muscadines.

Muscadine grape cultivars differed in the number of berries per cluster (Figs. 7 and 8 ). The number of berries per cluster was the greatest in 'Redgate' (23.2), whereas 'Polyanna' had the fewest (7.1). Differences among cultivars were also detected for yield (Figs. 9 and 10). The highest yielding cultivar was Janebell (51.7 kg/vine), whereas the lowest yielding cultivar was Burgaw (10.2 kg/vine). 'Carlos', 'Doreen', 'Fry' 'Higgins', 'Magnolia', 'Nesbit', 'Noble', 'Redgate', 'Southern Home', 'Sterling', 'Watergate', and 'Welder' also produced high yields (>38 kg/vine). A significant correlation was detected between yield and vine vigor $(r=0.33, P \leq 0.05)$, but not between yield and other variables.

Differences among muscadine grape cultivars were detected for all quality factors including berry size, number of seeds per berry, percentage of berries with picking scars, firmness, $\mathrm{pH}$, and soluble solids content. Fruit of 'Black Beauty' and 'Darlene' were the largest berries (14.6 g), whereas the berries of 'Noble' were the smallest (3.0 g) (Figs. 11 and 12). Other cultivars having large $(>10 \mathrm{~g})$ berries included Fry, Jumbo, Sweet Jenny, and Tara. 'Dixieland' had the greatest number of seeds per berry (4.0 seeds/berry), whereas 'Dulcet' had the fewest (2.4 seeds/berry) (Figs. 13 and 14). Fruit of cultivars best suited for mechanical harvest and for longer shelf life have a high percentage of dry picking scars. Of the cultivars evaluated, Southland had

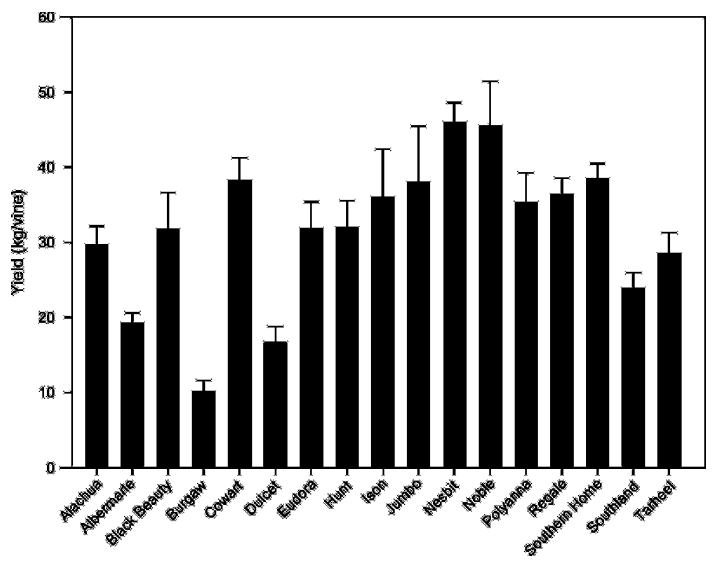

Fig. 7. Average yield of black-skinned muscadine grape cultivars evaluated at $\mathrm{McNeil}, \mathrm{MS}$, in 2001,

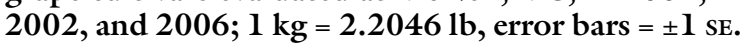

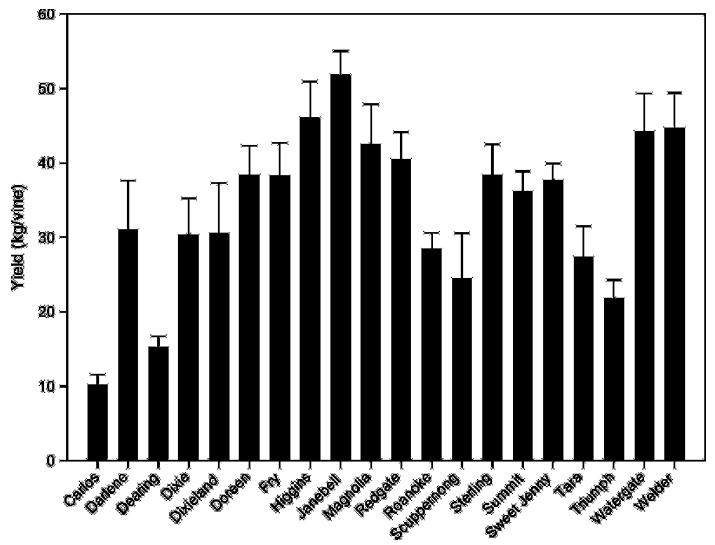

Fig. 8. Average yield of red- and bronze-skinned muscadine grape cultivars evaluated at $\mathrm{McNeil}$, MS, in 2001,2002 , and $2006 ; 1 \mathrm{~kg}=2.2046 \mathrm{lb}$, error bars $= \pm 1 \mathrm{SE}$.

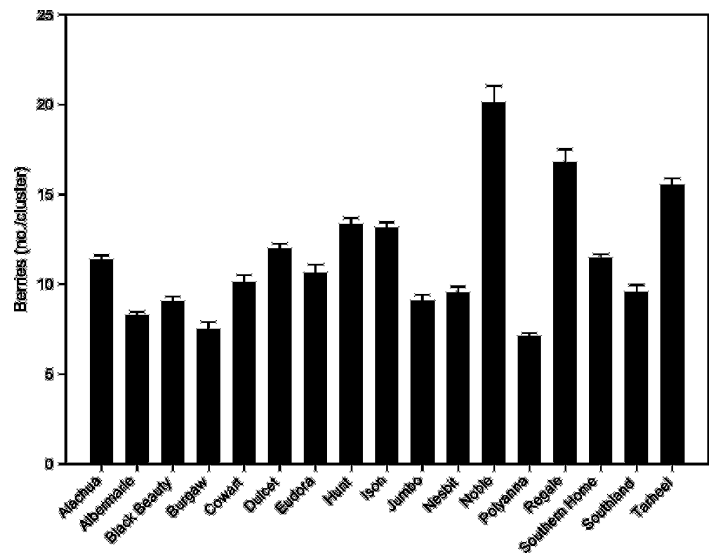

Fig. 9. Average number of berries per cluster of black-skinned muscadine grape cultivars evaluated at McNeil, MS, in 2001, 2002, and 2006; error bars $= \pm 1$ SE.

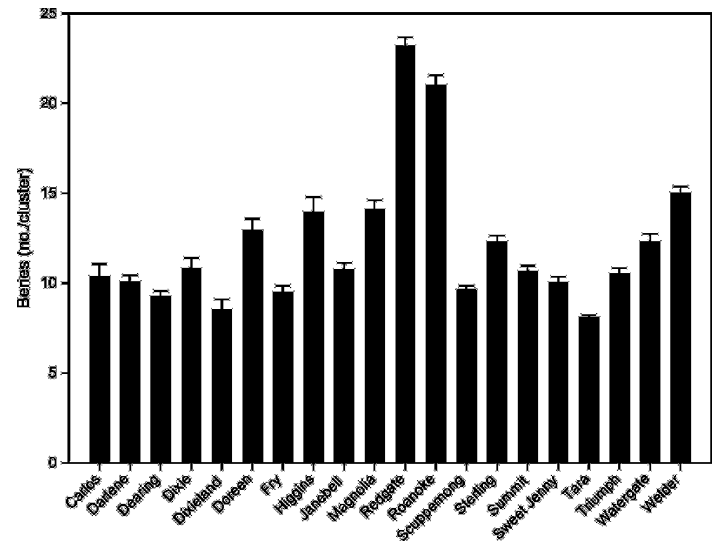

Fig. 10. Average number of berries per cluster of redand bronze-skinned muscadine grape cultivars evaluated at McNeil, MS, in 2001, 2002, and 2006; error bars $= \pm 1 \mathrm{SE}$. 


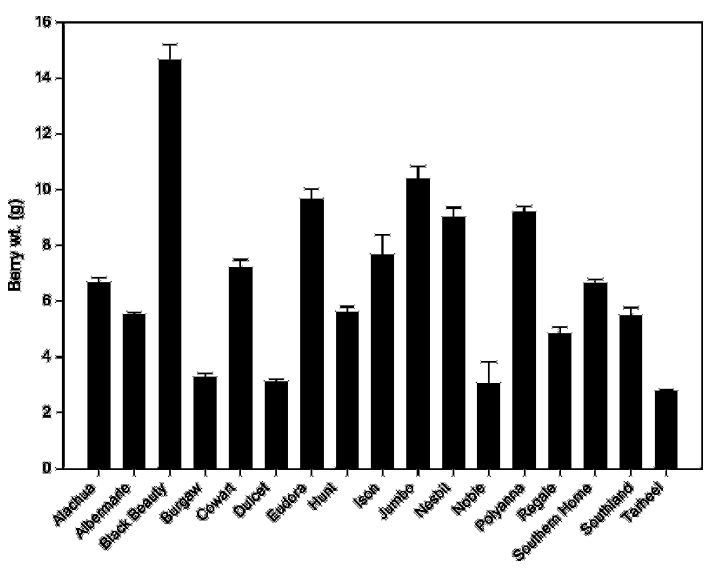

Fig. 11. Average berry weight of black-skinned muscadine grape cultivars evaluated at McNeil,

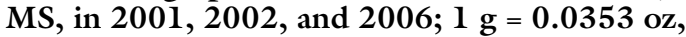
error bars $= \pm 1 \mathrm{SE}$.

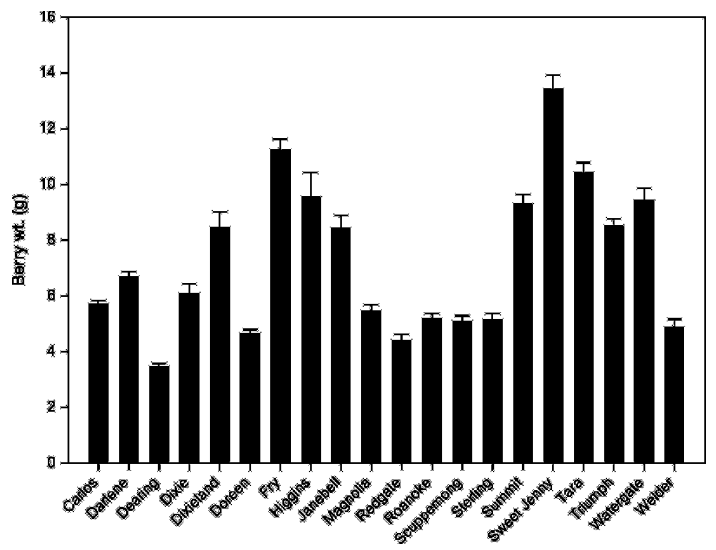

Fig. 12. Average berry weight of red- and bronzeskinned muscadine grape cultivars evaluated at $\mathrm{McNeil}, \mathrm{MS}$, in 2001, 2002, and 2006; $1 \mathrm{~g}=0.0353$ $\mathrm{oz}$, error bars $= \pm 1$ SE.

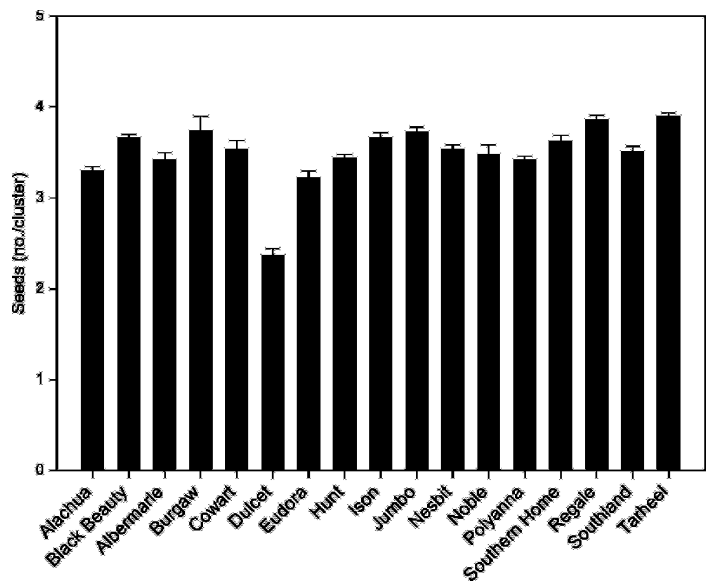

Fig. 13. Average number of seeds per berry of black-skinned muscadine grape cultivars evaluated at $\mathrm{McNeil}, \mathrm{MS}$, in 2001, 2002, and 2006; error bars $= \pm 1$ SE.

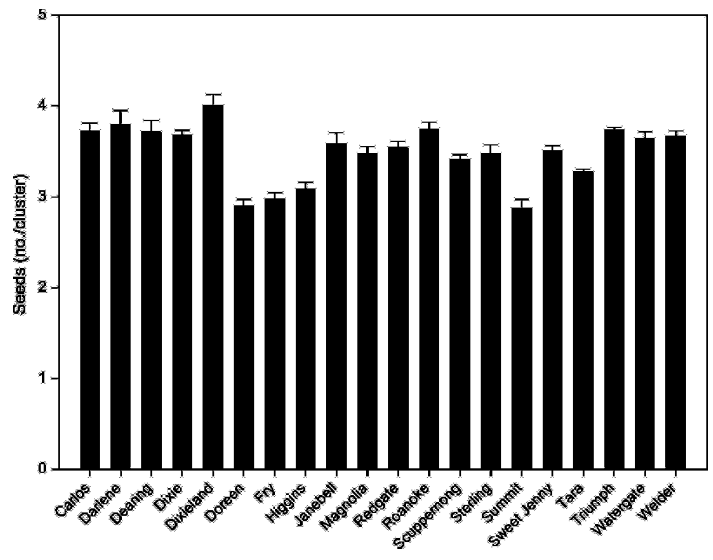

Fig. 14. Average number of seeds per berry of redand bronze-skinned muscadine grape cultivars evaluated at McNeil, MS, in 2001, 2002, and 2006; error bars $= \pm 1 \mathrm{SE}$.

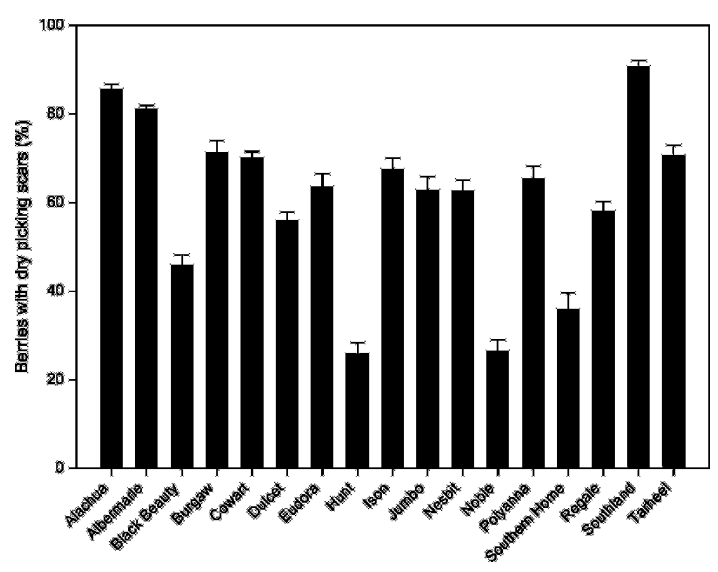

Fig. 15. Average percentage of berries of blacksinned muscadine grape cultivars with dry picking scars evaluated at McNeil, MS, in 2001, 2002, and 2006; error bars $= \pm 1$ SE.

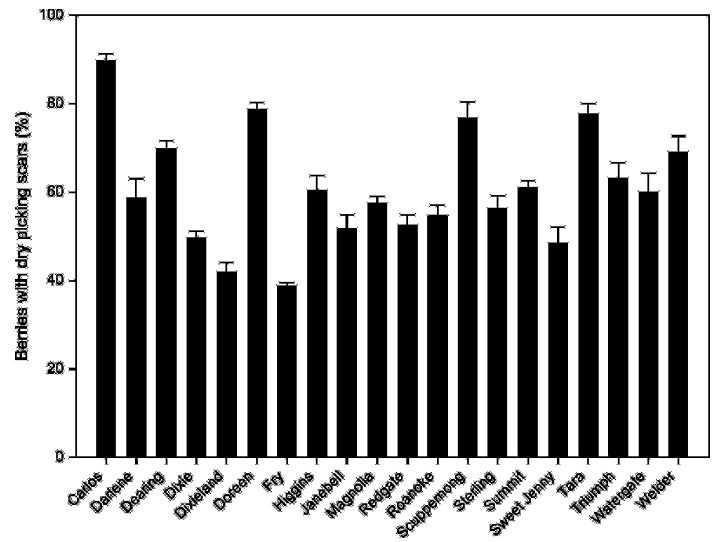

Fig. 16. Average percentage of berries of red- and bronze-skinned grape cultivars with dry picking scars evaluated at McNeil, MS, in 2001, 2002, and 2006; error bars $= \pm 1 \mathrm{sE}$. 


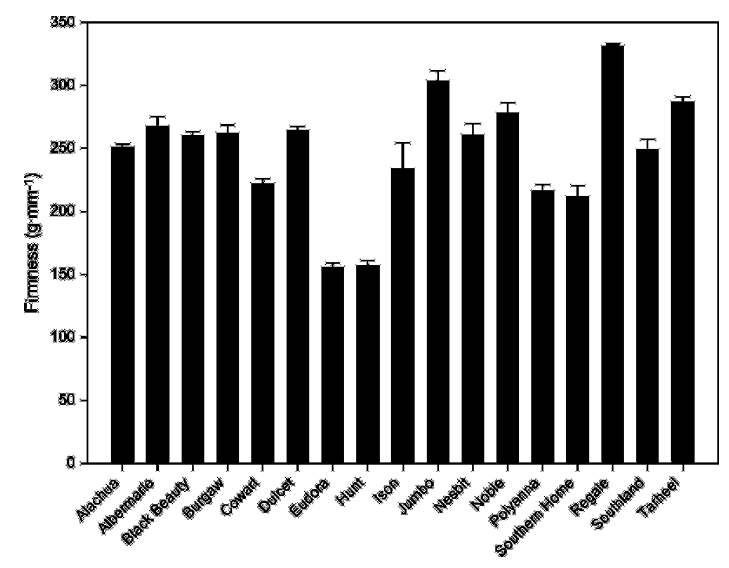

Fig. 17. Average berry firmness (grams per $1 \mathrm{~mm}$ of deflection) of black-skinned muscadine grape cultivars evaluated at McNeil, MS, in 2001, 2002, and 2006; $1 \mathrm{~g}=0.0353 \mathrm{oz}, 1 \mathrm{~mm}=0.0394 \mathrm{inch}$, error bars $= \pm 1 \mathrm{SE}$.

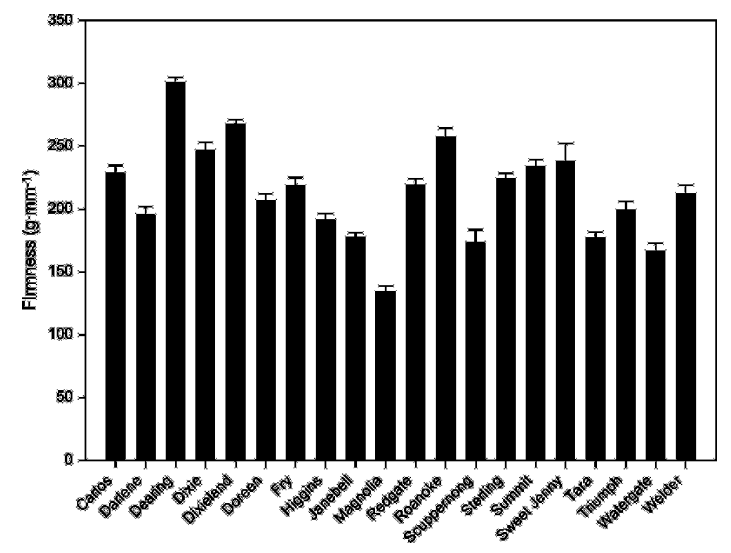

Fig. 18. Average berry firmness (grams per $1 \mathrm{~mm}$ of deflection) of red- and bronze-skinned muscadine grape cultivars evaluated at $\mathrm{McNeil}, \mathrm{MS}$, in 2001, 2002 , and 2006; $1 \mathrm{~g}=0.0353 \mathrm{oz}, 1 \mathrm{~mm}=0.0394$ inch, error bars $= \pm 1$ SE.

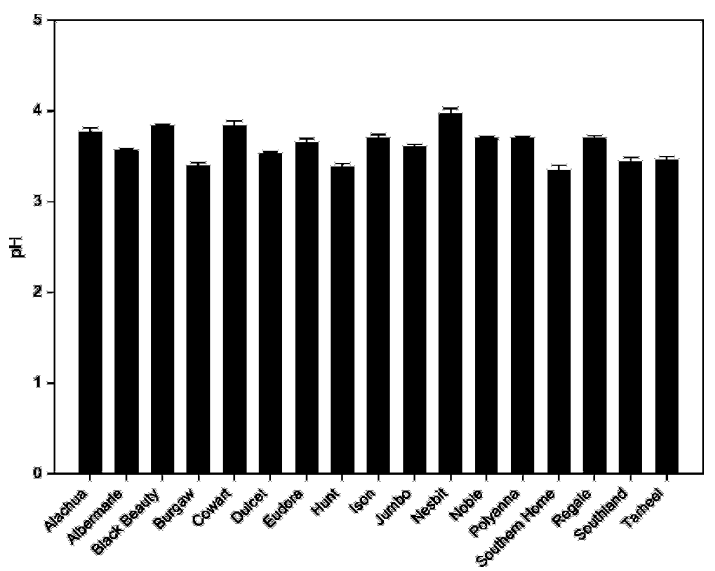

Fig. 19. Average berry $\mathrm{pH}$ of black-skinned muscadine grape cultivars evaluated at $\mathrm{McNeil}$, MS, in 2001, 2002, and 2006; error bars $= \pm 1 \mathrm{SE}$.

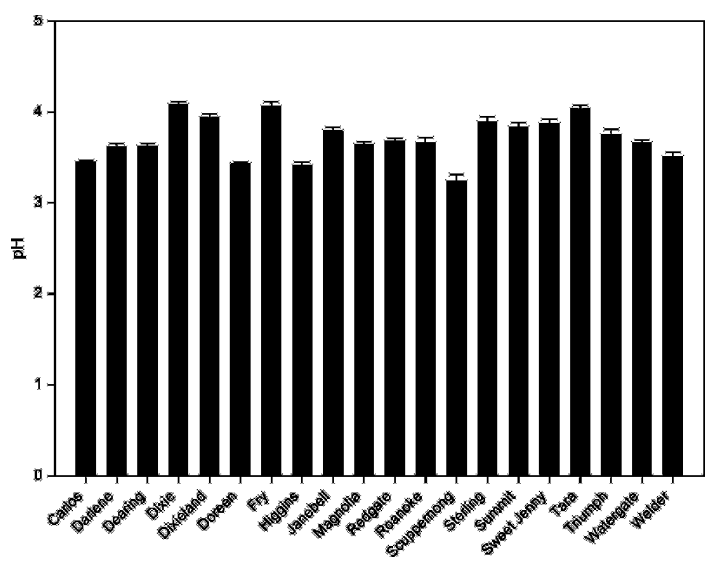

Fig. 20. Average berry $\mathrm{pH}$ of red- and bronzeskinned muscadine grape cultivars evaluated at McNeil, MS, in 2001, 2002, and 2006; error bars $= \pm 1 \mathrm{SE}$.

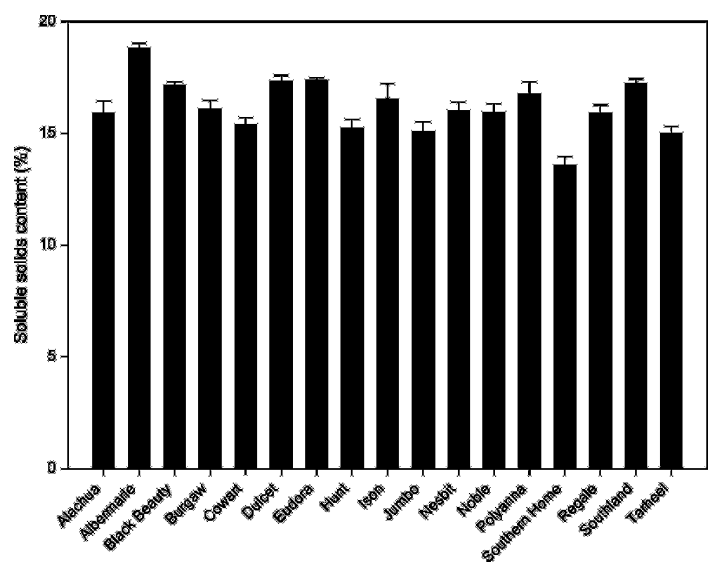

Fig. 21. Average solid solids content of blackskinned muscadine grape cultivars evaluated at McNeil, MS, in 2001, 2002, and 2006; error bars $= \pm 1$ SE.

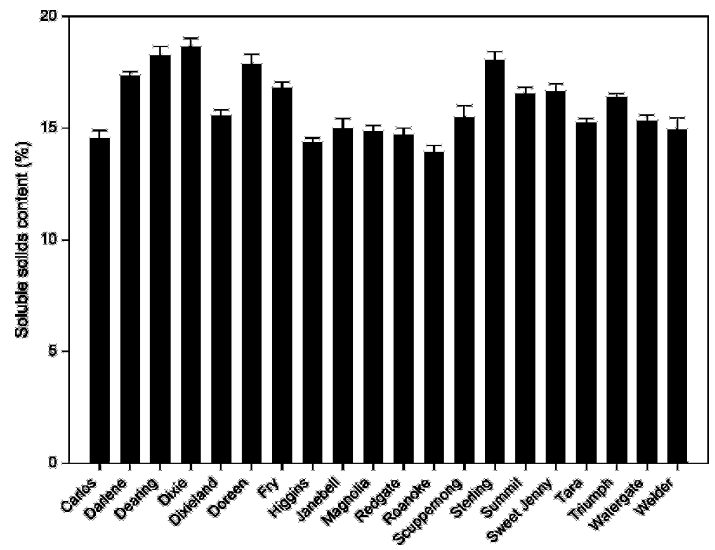

Fig. 22. Average solid solids content of red- and bronze-skinned muscadine grape cultivars evaluated at $\mathrm{McNeil}, \mathrm{MS}$, in 2001, 2002, and 2006; error bars $= \pm 1$ SE. 
the most berries with dry picking scars $(90.6 \%)$ and Regale had the fewest $(35.7 \%)$ (Figs. 15 and 16). Greater berry firmness is also important in reducing the incidence of fruit bruising at harvest and during transport, and ultimately results in greater storage quality. Measurements of berry firmness ranged from $163.4 \mathrm{~g} \cdot \mathrm{mm}^{-1}$ on fruit of 'Watergate' to 303.6 $\mathrm{g} \cdot \mathrm{mm}^{-1}$ on berries of 'Tara' (Fig. 17 and 18$)$. A significant correlation $(\mathrm{r}=$ $0.44, P \leq 0.01)$ was also detected between berry firmness and resistance to berry rot diseases.

Muscadine grape cultivars differed in other quality components affecting nutritional value, including $\mathrm{pH}$ (Figs. 19 and 20) and soluble solids content (Figs. 21 and 22). Berry $\mathrm{pH}$ was highest in fruit of 'Dixie' (4.1) and lowest in 'Scuppernong' (3.2). Soluble solids concentration was greatest in berries of 'Dixie' $(18.6 \%)$ and lowest in fruit of 'Regale' (13.5\%). A comparison of cultivars common to previous trials conducted in Florida $(\mathrm{n}=17)$ (Mortensen and Harris, 1989) or in Arkansas $(\mathrm{n}=1 \mathrm{l})$ (Striegler et al., 2005) revealed that soluble solids content was $1.4 \%$ and $1.7 \%$ higher, respectively, in their trials than in ours. This may have resulted from a combination of environmental factors affecting berry quality and from the hastened harvests that were necessary minimize bee and wasp injury to fruit.

Results of this evaluation identified several muscadine grape cultivars with performance and quality attributes useful in further breeding and genetics research for the development of new muscadine germplasm and cultivars. Moreover, these trials provided information for use by growers and nurserymen in the selection and propagation of the most suitable muscadine grape cultivars for establishing commercial and hobbyist vineyards in the Gulf of Mexico coastal region of the United States. Proven cultivars, including Dixie (multipurpose), Carlos, Doreen, Magnolia, Noble, Regale, Sterling and Welder (wine and juice), and Black Beauty, Fry, Nesbit, and Summit (fresh), all performed well and should be considered for commercial and home use. Newer cultivars, including Southern
Home (multipurpose) and Eudora (fresh-market), also performed well and should be considered for trial plantings.

\section{Literature cited}

Armstrong, W.D., T.A. Pickett, and M.M. Murphy, Jr. 1934. Muscadine grapes, culture, varieties, and some properties of juice. Georgia Agr. Expt. Sta. Bul. 185.

Basiouny, F.M. 2001. Physiology and postharvest technology, p. 273-310. In: F.M. Basinouny and D.G. Himelrick (eds.). Muscadine grapes. ASHS Press, Alexandria, VA.

Braswell, J., S.J. Stringer, B.M. Sampson, and J. Ingram. 2001. Establishment and maintenance of muscadine grapes. Mississippi State Coop. Ext. Ser. Publ. 2290.

Brooks, R.M. and H.P. Olmo. 1997. Grape, p. 248-299. In: Register of new fruit and nut varieties. ASHS Press, Alexandria, VA.

Cathy, H.M. 1990. USDA hardiness zone map. U.S. Dept. Agr. Misc. Publ. 1475.

Clark, J.R. 2001. Evaluation of muscadine grape cultivars for productivity, fruit quality, and winter hardiness in Arkansas, 1987-1988. Arkansas Agr. Expt. Sta. Spec. Rpt. 203.

Ector, B.J. 2001. Compositional and nutritional characteristics, p. 341-367. In: F.M. Basinouny and D.G. Himelrick (eds.). Muscadine grapes. ASHS Press, Alexandria, VA.

Goffinet, M.C., M.J. Wesler, and D.G. Himelrick. 2001. Anatomy and morphology, p. 15-50. In: F.M. Basinouny and D.G. Himelrick (eds.). Muscadine grapes. ASHS Press, Alexandria, VA.

Hartle, D.K., P. Grenspan, and J.L. Hargrove. 2005. Muscadine medicine. Blue Heron Nutraceuticals, St. George Island, FL.

Himelrick, D.G. 2001. Vineyard site selection, establishment, and floor management, p. 133-151. In: F.M. Basinouny and D.G. Himelrick (eds.). Muscadine grapes. ASHS Press, Alexandria, VA.

Hopkins, D.L., H.H. Mollenhauer, and J.A. Mortensen. 1974. Tolerance to pierce's disease and the associated rickettsialike bacterium in muscadine grapes. J. Amer. Soc. Hort. Sci. 99:436-439.
Husman, G.C. and C. Dearing. 1913. The muscadine grapes. U.S. Dept. Agr. Bur. Plant Ind. Bul. 273.

Maas, J., G. Galletta, and G. Stoner. 1991. Ellagic acid, an anticarcinogen in fruits, especially in strawberries: A review. HortScience 26:10-14.

Moore, J.N. 1972. Performance of muscadine grape cultivars in Arkansas. Arkansas Agr. Expt. Sta. Rpt. Ser. 200.

Moore, J.N. and H.L. Bowden. 1976. Muscadine grapes in east central Arkansas. Arkansas Farm Res. 25:4.

Morris, J.R. and P.L. Brady. 2004. The muscadine experience: Adding value to enhance profits. Univ. Arkansas Agr. Expt. Sta. Res. Rpt. 974.

Mortensen, J.A. 2001. Cultivars, p. 91-105. In: F.M. Basinouny and D.G. Himelrick (eds.). Muscadine grapes. ASHS Press, Alexandria, VA.

Mortensen, J.A. and C.F. Balderdi. 1973. Muscadine grapes for Florida: Yields and other characteristics of 48 cultivars. Proc. Florida State Hort. Soc. 86:338-341.

Mortensen, J.A. and J.W. Harris. 1989. Yields and other characteristics of muscadine grapes at Leesburg. Proc. Florida State Hort. Soc. 102:223-226.

Mortensen, J.A., L.H. Stover, and C.F. Balderi. 1977. Sources of resistance to pierce's disease in Vitis. J. Amer. Soc. Hort. Sci. 102:695-697.

Olein, W.C. 1990. The muscadine grape: Botany, viticulture, history, and current industry. HortScience 25:732-739.

Sampson, B.J., S. Noffsinger, C. Gupton, and J. Magee. 2001. Pollination biology of the muscadine grape. HortScience 36:120-124.

Striegler, R.K., J.R. Morris, P.M. Carter, R.T. Threfall, and L.R. Howard. 2005. Yield, quality, and nutraceutical potential of selected muscadine cultivars grown in southwestern Arkansas. HortTechnology 15:276-284.

Stringer, S.J., D. Gray, and J.M. Spiers. 2007. Notice to nurserymen of the naming and release for propagation of 'Eudora', a new muscadine grape cultivar. U.S. Dept. Agr., Agr. Res. Serv., Washington, DC.

U.S. Department of Agriculture. 1983. Soil survey of Pearl River County, Mississippi. P. Nichols, A.R. Leggett, and L.B. Wilson (eds.). U.S. Dept. Agr. Soil Conservation Serv. in cooperation with Mississippi Agr. For. Expt. Sta. 